\title{
'Alboraia' and 'Bonrepos': The First Registered Chufa (Cyperus esculentus L. var. sativus Boeck.) Cultivars
}

\author{
Nuria Pascual-Seva, Alberto San Bautista, Salvador V. López-Galarza, \\ José V. Maroto, and Bernardo Pascual ${ }^{1}$ \\ Departamento de Producción Vegetal, Universitat Politècnica de València, \\ Camino de Vera s/n, 46022, Valencia, Spain
}

Additional index words. tuber, yield, sensory analysis, clonal selection

Cyperus esculentus L. can be found wild, weedy, or in a cultivated state. It is an abundant weed in all mild and tropical zones and is considered one of the most important and hard-to-control weeds worldwide, although it is not as noxious as Cyperus rotundus L. (Holm et al., 1977). Usually, the wild and weedy plants are known as yellow nutsedge, and the cultivated plants, C. esculentus L. var. sativus Boeck., are known as chufa or tigernut. Chufa has been cultivated since the fourth millennium in Egypt and for several centuries in southern Europe (Pascual et al., 2000a), where it has never become an invasive weed in the cultivation area. It has been also cultivated in the United States for livestock feeding, especially for being pastured by pigs (Killinger and Stokes, 1951).

Currently, chufa (Fig. 1) is an important vegetable crop in the Horta Nord area of the Valencia region (Spain). The acreage annually dedicated to the chufa crop is $\approx 500$ ha with a production of 6.5 to $10^{6} \mathrm{t}$ and a value of 4 to $10^{6} €$. Chufa tubers are used to produce a beverage called horchata or "horchata de chufas" (chufa milk), which is a popular, refreshing, and wholesome drink in Spain. It is the milky aqueous extract of chufa tubers prepared adding sugar so that their minimum contents in fat, starch, and sugars are $2.5 \%$, $2.2 \%$, and $12^{\circ}$ Brix, respectively (CRDO, 2012). Annually, $\approx 46$ to $10^{6} \mathrm{~L}$ of horchata are produced, representing a retail market value of 32 to $10^{6} €$ (INE, 2012). Horchata has recently become popular in other countries such as France, the United Kingdom, the United States, and Argentina. Fresh chufa tubers can also be consumed on their own after soaking, although most of the crop is destined to horchata production. In Spain, the consumption of horchata is increasing; therefore, the Regional Administration of the Valencian Community has developed specific legislation regarding chufa qualitative parameters (CAPA, 2010). An increasing interest has been reported in chufa cultivation, mostly for food technology and biodiesel production, in Brazil, Cameroon, China,

Received for publication 5 Dec. 2012. Accepted for publication 15 Jan. 2013.

${ }^{1}$ To whom reprint requests should be addressed; e-mailbpascual@prv.upv.es.
Egypt, Hungary, the Republic of Korea, Poland, Turkey, and the United States (Pascual-Seva et al., 2009).

Traditionally, growers have used chufa landraces, and no breeding programs have been undertaken. Compared with the most important local landrace, the two new cultivars presented here significantly increase yield, and their tubers produce horchata of higher quality. Initially identified and evaluated as Clones 3 and 4 , the cultivars are named after the towns of Bonrepos and Alboraia, respectively, which are the municipalities where the original tuber samples were taken from. Although the names Bonrepos and Alboraia were only given at the end of the selection and evaluation process, for purposes of clarity, Clones 3 and 4 are thereafter called clones Bonrepos and Alboraia (Fig. 2).

\section{Origin}

A comprehensive sampling was performed among tubers used by farmers in the traditional area of cultivation as well as from populations of African origin followed by plant characterization based on the morphological and agronomic plant traits and morphological traits and chemical composition of the tubers was conducted in a seven-year research project (Pascual et al., 2000b). A clonal selection was conducted based on the results of this characterization.

Using the traits that presented sufficient heritability, a discriminant analysis was performed every year to assign the different clones into uniform clusters and to reduce the number of clones to be studied in successive programs selecting within each cluster the clones that presented the best traits. The random amplified polymorphic DNA technique was used to determine the genetic relationships among several chufa clones (including both autochthonous and from African origin) and two yellow nutsedge populations (Abad et al., 1998). A genetic similarity matrix was constructed based on the banding pattern and subjected to the unweighted pair group method using arithmetic averages cluster analysis. A dendrogram produced from this analysis delineated two different clusters. Cluster A included two clones obtained from the local chufa populations (clones Bonrepos and Alboraia) and a clone from Ghana (7); Cluster B included the two weedy clones and a chufa clone from Togo (Clone 2). Plants of each clone were started from tubers produced from a single plant grown in a pot outdoors.

\section{Performance}

Chufa Clones 2, Bonrepos, Alboraia, and 7 were evaluated for tuber production and tuber traits. An accession (samples collected from the farmers' fields for the purpose of this research) of the well-known chufa landrace 'Llargueta' (the most important population grown by farmers in the traditional area of cultivation) was included as a control. The experiments were conducted over three consecutive years $(2009,2010$, and 2011) on a commercial farm near the Valencia Polytechnic University campus in Spain (lat. $39^{\circ} 29^{\prime} \mathrm{N}$, long. $0^{\circ} 20^{\prime} \mathrm{W}$ ) within the main production area of chufa. This farm is representative of the plots in the region. According to the Papadakis agroclimatic classification system (MOPT, 1992), the climate is subtropical Mediterranean with hot, dry summers and an average annual rainfall of $\approx 450 \mathrm{~mm}$. The soil of the experimental plot was classified as anthropic torrifluvents according to the USDA Soil Taxonomy (Soil Survey Staff, 2010) and was characterized as loamy sand, slightly alkaline $(\mathrm{pH}=7.81)$ with low electrical conductivity $\left(0.41 \mathrm{mS} \cdot \mathrm{cm}^{-1}\right)$ and high organic matter content $(2.16 \%)$. The soil nutrient

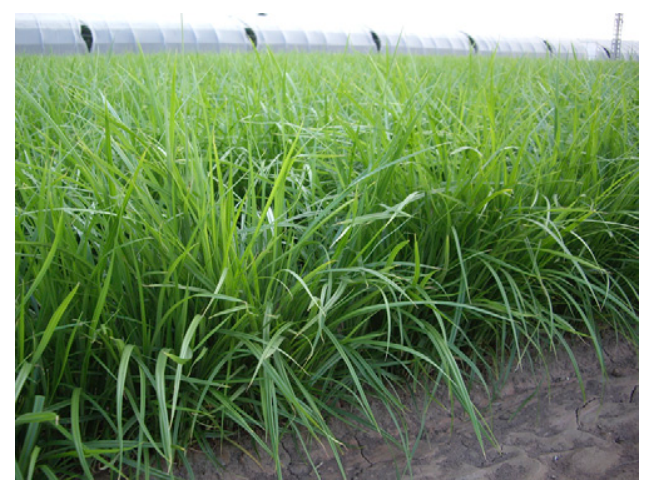

Fig. 1. Chufa plants. 
contents included phosphorus (169 $\left.\mathrm{mg} \cdot \mathrm{kg}^{-1}\right)$, potassium $\left(443 \mathrm{mg} \cdot \mathrm{kg}^{-1}\right)$, and nitrogen $(0.17 \%)$. The standard cultivation practices described by Pascual et al. (1997) were followed during the crop period. We used a randomized complete block design with four replicates.

The morphological tuber traits presented in this article are the mean values of 50 tubers selected at random, after washing with tap water, from each primary sample, which consisted of $3 \mathrm{~kg}$ of tubers taken from each replicate of each clone/landrace and growing season. The selected tubers were weighed and longitudinally (L) and transversely (W) measured, and the $\mathrm{L} / \mathrm{W}$ ratio, which was considered to be a direct index of tuber shape, establishing the following scale: L/W less than 1.3: spherical; $1.3 \leq \mathrm{L} / \mathrm{W} \leq 1.8$ : ovoid; $\mathrm{L} / \mathrm{W}$ greater than 1.8: elongated, was measured (Pascual et al., 2000b).

After washing, $200 \mathrm{~g}$ of tubers from each primary sample were dried at $65{ }^{\circ} \mathrm{C}$ in a forced-air oven until constant weight to determine the residual moisture. The tubers were then mineralized and analyzed for their proximate composition following the analytical methods described by the Association of Official Analytical Chemists (AOAC International, 2000): fat, total sugar, protein $(6.25 \times \mathrm{N})$, and fiber contents. Starch content was determined by the Antrona-sulfuric method (McCredy et al., 1950).

Part of the four primary samples $(500 \mathrm{~g})$ of each growing season and clone/landrace was combined and mixed to obtain (in triplicate) horchata following the recommendations of the Regulatory Council of Denomination of Chufa Origin of Valencia, Spain (CRDO, 2012) and was filled into $1500-\mathrm{mL}$ plastic bottles and stored at $2{ }^{\circ} \mathrm{C}$.

Eight trained panelists estimated the overall acceptability on a 9-point hedonic scale (with the 1 and 9 values corresponding to "extremely dislike" and "extremely like" scores) and the texture on a 4-point scale (with 1 and 4 values corresponding to the less consistent and the most consistent scores) of the horchata samples, in agreement with Morell and Barber (1983).

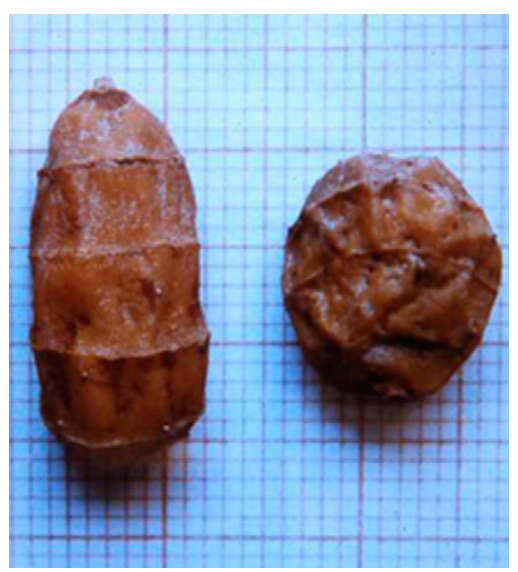

Fig. 2. Tubers of 'Alboraia' (left) and 'Bonrepos' (right).
Data were analyzed using the analysis of variance procedures of Statgraphics 5.1 Plus (Statistical Graphics Corporation, 2005) and tested for significance at $P \leq 0.05$. Mean separation was performed according to the least significance difference test.

Neither the yield nor any of the studied tuber morphological traits were significantly affected by the growing season or the interaction growing season $\times$ clone/landrace (Table 1). However, significant differences were found among clones/landrace for these traits. Clone Alboraia produced a yield (on average $20.9 \mathrm{t} \cdot \mathrm{ha}^{-1}$ ) comparable to clone Bonrepos (20.0 t.ha $\left.{ }^{-1}\right)$ and significantly higher than 'Llargueta' (19.1 t.ha $\left.{ }^{-1}\right)$ and Clones $2\left(15.6 \mathrm{t} \cdot \mathrm{ha}^{-1}\right)$ and $7\left(16.8 \mathrm{t} \cdot \mathrm{ha}^{-1}\right)$; the yield of clone Bonrepos was comparable to 'Llargueta' and significantly higher than remaining clones. The yields of the autochthonous clones exceed those obtained by local growers with 'Llargueta' in these growing seasons (ranging from 18.2 to $18.5 \mathrm{t} \cdot \mathrm{ha}^{-1}$; MAGRAMA, 2012a; CRDO, personal communication), whereas the yield of the clones of African origin (2 and 7) were significantly lower.

Regarding the tuber shape, two groups can be distinguished: one characterized by its spherical shape, with clones Bonrepos $(\mathrm{L} / \mathrm{W}=1.1)$ and $7(\mathrm{~L} / \mathrm{W}=1.0)$, and the other characterized by its ovoid shape, with clones Alboraia $(\mathrm{L} / \mathrm{W}=1.8), 2(\mathrm{~L} / \mathrm{W}=1.5)$, and 'Llargueta' $(\mathrm{L} / \mathrm{W}=1.8)$. There were significant differences in relation to the size (measured as length) and tuber weight (TW) between clones. Among the spherical tubers, those of Clone 7 were larger $(\mathrm{L}=14.0 \mathrm{~mm})$ and had a higher TW $(1.4 \mathrm{~g})$ than those from clone Bonrepos (11.9 mm; $0.8 \mathrm{~g})$. Among the ovoid tubers, Clone 2 weighed more per unit $(1.1 \mathrm{~g})$ than those of clone Alboraia $(0.9 \mathrm{~g})$ and 'Llargueta' ( $0.9 \mathrm{~g})$. There were no significant differences in size, shape, or TW between tubers of clone Alboraia and 'Llargueta'. The morphological traits of the tubers produced by Clones 2, Bonrepos, and Alboraia obtained in this study were similar to those obtained in the previously cited study regarding the selection and characterization of chufa cultivars
(Pascual et al., 2000b), implying that these traits are stable, accomplishing the stability requirement of the International Union for the Protection of New Varieties of Plants (UPOV; UPOV, 2011).

To compare the variability of the tuber morphological traits within each clone/landrace, the corresponding coefficients of variation were determined. The coefficients of variation of $\mathrm{L}, \mathrm{L} / \mathrm{W}$, and TW showed marked differences between 'Llargueta' (on average $0.2,0.3$, and 0.3 for $\mathrm{L}, \mathrm{L} / \mathrm{W}$, and $\mathrm{TW}$, respectively) and the assayed clones $(0.1$, 0.2 , and $0.2 ; 0.1,0.1$, and $0.2 ; 0.1,0.2$, and $0.2 ; 0.1,0.1$, and 0.2; for Clones 2, Bonrepos, Alboraia, and 7, respectively). Uniformity is favorable for tuber commercialization and the UPOV convention for the protection of new varieties (UPOV, 2011) requires sufficient uniformity. The tuber uniformity is larger (lower $\mathrm{CV}$ ) for selected clones than for 'Llargueta' as a consequence of the clonal selection conducted in their generation.

The values of fiber, starch, fat, and total sugar contents differ significantly among growing seasons, and the values of starch, fat, and total sugar contents differ significantly among clones/landrace (Table 2 ). The tubers of clones Bonrepos and Alboraia and 'Llargueta' had comparable compositions of fiber, starch, fat, and protein, showing higher values of fat $(29.3 \%, 29.1 \%$, and $28.7 \%$, respectively) and lower values of starch $(36.7 \%$, $36.8 \%$, and $36.9 \%$, respectively) contents than those of Clone 2 (fat: $25.5 \%$, starch: $40.4 \%$ ). The sugar content of 'Llargueta' $(13.8 \%)$ was significantly lower than that of clones Bonrepos (14.4\%) and Alboraia $(14.5 \%)$. The tubers of Clone 7 showed a significantly higher fat content and lower starch and sugar contents in comparison with those of Clone 2.

Although the chemical composition of tubers generally presents low heritability (Pascual et al., 2000b), the proximate compositions of the tubers produced by Clones 2 , Bonrepos, and Alboraia were comparable to those obtained in the previously mentioned selection and characterization of chufa cultivars

Table 1. The effect of the growing season and clone/landrace on yield traits.

\begin{tabular}{lcccc}
\hline & Yield $\left(\mathrm{t} \cdot \mathrm{ha}^{-1}\right)$ & Length $(\mathrm{mm})$ & Length/width & Unit wt $(\mathrm{g})$ \\
\hline Growing season & & & & \\
2009 & 18.0 & 15.5 & 1.4 & 1.1 \\
2010 & 18.1 & 15.3 & 1.4 & 0.7 \\
$\quad 2011$ & 19.3 & 15.8 & 1.4 & 1.0 \\
Clones/landrace & & & & \\
2 & $15.6 \mathrm{c}$ & $17.2 \mathrm{a}$ & $1.5 \mathrm{~b}$ & $1.1 \mathrm{~b}$ \\
Bonrepos & $20.0 \mathrm{ab}$ & $11.9 \mathrm{c}$ & $1.1 \mathrm{c}$ & $0.7 \mathrm{~d}$ \\
Alboraia & $20.9 \mathrm{a}$ & $17.1 \mathrm{a}$ & $1.8 \mathrm{a}$ & $0.9 \mathrm{c}$ \\
7 & $16.8 \mathrm{c}$ & $14.3 \mathrm{~b}$ & $1.0 \mathrm{~d}$ & $1.4 \mathrm{a}$ \\
'Llargueta' & $19.1 \mathrm{~b}$ & $17.1 \mathrm{a}$ & $1.8 \mathrm{a}$ & $0.8 \mathrm{~cd}$
\end{tabular}

Analysis of variance

Factor (df)

Growing season (2)

Clones/landrace (4)

Growing season $\times$ clones/landrace $(8)$

Residual (46)

${ }^{2}$ For every factor, different letters in the same column indicate significant differences at $P \leq 0.05$ according to the least significant difference test

**, NS Significant differences at $P \leq 0.01$ or nonsignificant, respectively. 
(Pascual et al., 2000b). The tuber fat contents of clones Bonrepos and Alboraia and 'Llargueta' were slightly higher than those usually reported for Spanish tubers (Morell and Barber, 1983; Pascual et al., 2000b) and higher than those reported for Nigerian (Ade-Omowaye et al., 2009), Egyptian (Abdel-Nabey, 2001), and Turkish tubers (Coskuner et al., 2002). However, they are comparable to those reported by Umerie et al. (1997) for Nigerian tubers. The proximate tuber composition of all clones and 'Llargueta' surpassed the minimum values required by the Regional Administration Legislation (\% dry mass: fats 23 or greater, proteins 6.5 or greater, starch 25 or greater, and sugars 11 or greater; CAPA, 2010).

In the sensory analysis evaluations, the panelists found significant differences (Table 3 ) between horchatas obtained from different clones/landrace. The panelists significantly appreciated (larger overall acceptability; A) horchatas produced from clones Bonrepos $(\mathrm{A}=7.4)$ and Alboraia $(\mathrm{A}=7.4)$ more than those from 'Llargueta' $(\mathrm{A}=7.1)$. However, significant differences were not found for horchata texture $(\mathrm{T})$ values $(3.2,3.2$, and 3.2 for clones Bonrepos and Alboraia and 'Llargueta', respectively). The horchatas from Clones 2 and 7 received the lowest $\mathrm{A}$ and $\mathrm{T}$ values [Clone $2(\mathrm{~A}=5.7 ; \mathrm{T}=2.7)$ and Clone $7(\mathrm{~A}=6.2 ; \mathrm{T}=2.9)]$. It has been stated, as expected and agreeing with the general belief, that the higher the horchata fat content (in this case, tuber fat content), the higher the consumer appreciation.

Clones Bonrepos and Alboraia accomplished the three requirements of the UPOV to be considered new cultivars: distinctness, uniformity, and stability. Furthermore, these clones are highly productive, and their tubers produced the most appreciated horchatas in

Table 2. The effect of the growing season and clone/landrace on tuber proximate composition.

\begin{tabular}{lccccc}
\hline & Fiber & Starch & Fat & Protein & Sugar \\
\hline Growing season & & & & & \\
2009 & $8.5 \mathrm{a}^{\mathrm{z}}$ & $33.7 \mathrm{c}$ & $29.2 \mathrm{a}$ & 8.9 & $16.8 \mathrm{a}$ \\
2010 & $7.8 \mathrm{~b}$ & $38.3 \mathrm{~b}$ & $29.1 \mathrm{a}$ & 8.8 & $12.9 \mathrm{~b}$ \\
2011 & $7.1 \mathrm{c}$ & $40.5 \mathrm{a}$ & $26.5 \mathrm{~b}$ & 9.1 & $13.3 \mathrm{~b}$ \\
Clones/landrace & & & & & $15.1 \mathrm{a}$ \\
2 & 7.5 & $40.4 \mathrm{a}$ & $25.5 \mathrm{~b}$ & 9.7 & $14.4 \mathrm{ab}$ \\
Bonrepos & 7.8 & $36.7 \mathrm{~b}$ & $29.3 \mathrm{a}$ & 8.7 & $14.5 \mathrm{ab}$ \\
Alboraia & 7.9 & $36.8 \mathrm{~b}$ & $29.1 \mathrm{a}$ & 8.6 & $13.9 \mathrm{c}$ \\
7 & 8.0 & $36.6 \mathrm{~b}$ & $28.8 \mathrm{a}$ & 9.3 & $13.8 \mathrm{c}$
\end{tabular}

Analysis of variance

Factor (df)

Growing season (2)

Clones/landrace (4)

Growing season $\times$ clones/landrace $(8)$

Residual (46)

${ }^{2}$ For every factor, different letters in the same column indicate significant differences at $P \leq 0.05$ according to the least significant difference test.

**, *, NS Significant differences at $P \leq 0.01, P \leq 0.05$, or nonsignificant, respectively.

Table 3. The effect of the growing season, clone/landrace, and panelist on the overall appreciation and texture of horchatas.

\begin{tabular}{lcc}
\hline & Overall Appreciation & Texture \\
\hline Growing season & $7.0 \mathrm{a}^{\mathrm{z}}$ & $3.1 \mathrm{a}$ \\
2009 & $6.7 \mathrm{~b}$ & $3.1 \mathrm{a}$ \\
2010 & $6.7 \mathrm{~b}$ & $2.9 \mathrm{~b}$ \\
2011 & & \\
Clones/landrace & $5.7 \mathrm{~d}$ & $2.7 \mathrm{c}$ \\
2 & $7.4 \mathrm{a}$ & $3.2 \mathrm{a}$ \\
Bonrepos & $7.4 \mathrm{a}$ & $3.2 \mathrm{a}$ \\
Alboraia & $6.2 \mathrm{c}$ & $2.9 \mathrm{c}$ \\
7 & $7.1 \mathrm{~b}$ & $3.2 \mathrm{a}$
\end{tabular}

Analysis of variance

Factor (df)

Growing season (2)

Clones/landrace (4)

Panelist (7)

Growing season $\times$ clones/landrace $(8)$

Growing season $\times$ panelist (14)

Clones/landrace $\times$ panelist $(28)$

Growing season $\times$ clones/landrace $\times$ panelist (56)

Residual (62)

Percentage of the total sum of squares

${ }^{\mathrm{z}}$ For every factor, different letters in the same column indicate significant differences at $P \leq 0.05$ according to the least significant difference test.

**, Ns Significant differences at $P \leq 0.01$ or nonsignificant, respectively. the sensory evaluations. For these reasons, clones Bonrepos and Alboraia have been recently awarded the titles of new plant varieties by the Spanish Ministry of Agriculture (MAGRAMA, 2012b).

\section{Availability}

Small samples of 'Bonrepos' and 'Alboraia' tubers are available for research purposes (contact the corresponding author).

\section{Literature Cited}

Abad, P., B. Pascual, J.V. Maroto, S. LópezGalarza, M.J. Vicente, and J. Alagarda. 1998. RAPD analysis of cultivated and wild yellow nutsedge (Cyperus esculentus L.). Weed Sci. 46:318-321.

Abdel-Nabey, A.A. 2001. Chemical and technological studies on chufa (tiger nut) tubers (Cyperus esculentus L.). Alexandria J. Agr. Res. 46:71-80.

Ade-Omowaye, B.I.O., A.M. Adegbite, and B.R. Adetunji. 2009. Evaluation of some chemical and physicochemical properties of meals from pretreated tigernut seeds (Cyperus esculentus). Nutr. Food Sci. 39:142-150.

AOAC International. 2000. Official Methods of Analysis of AOAC International (17th ed.). Vol. I, chapter 4. AOAC International, Gaithersburg, MD.

CAPA (Conselleria de Agricultura, Pesca y Alimentación). 2010. Order 17/2010, of Conselleria de Agricultura, Pesca y Alimentación, approving the Reglament of the Denomination of Origin Chufa of Valencia and its Regulatory Council. Diari Oficial de la Comunitat Valenciana, Spain. Num. 6273/24.05.2010:21055-21069 [in Spanish].

Coskuner, Y., R. Ercan, E. Karababa, and A.N. Nazlican. 2002. Physical and chemical properties of chufa (Cyperus esculentus L.) tubers grown in the Çukurova region of Turkey. J. Sci. Food Agr. 82:625-631.

CRDO (Regulatory Council of Denomination of Origin Chufa of Valencia of Spain). 2012. Horchata of chufa; elaboration. Valencia, Spain. 5 Nov. 2012. <http://www.chufadevalencia. org $>$.

Holm, L.G., D.L. Plucknett, J.V. Pancho, and J.P. Herberger. 1977. The world's worst weeds: Distribution and biology. The University Press of Hawaii, Honolulu, HI.

INE (National Statistics Institute). 2012. Industrial products survey 2007. Madrid, Spain. 5 Nov. 2012 $<\mathrm{http} / / / \mathrm{www}$.ine.es/inebmenu/mnu_agricultura. htm>.

Killinger, G.B. and W.E. Stokes. 1951. Chufas in Florida. Bull 419. University of Florida, Agriculture Experimental Station, Gainesville, FL.

MAGRAMA (Spanish Ministry of Agriculture). 2012a. Statistical yearbook 2009. Madrid, Spain. 5 Nov. 2012. <http://www.magrama.gob.es/es/ estadistica/temas/ estadisticas-grarias/agricultura/ superficies-producciones-anuales-cultivos $>$ [in Spanish].

MAGRAMA (Spanish Ministry of Agriculture). 2012b. Order AAA/1403/2012 of 18 June which awards the titles of new plant variety on the Protected Varieties Register. Boletín Oficial del Estado. 154/28.06.2012:4606446065 [in Spanish].

McCredy, R.M., J. Guggolz, V. Silviera, and H.S. Owens. 1950. Determination of starch and amylose in vegetables. Anal. Chem. 22:1156-1158. MOPT (Spanish Ministry of Works). 1992. Guidelines for the preparation of studies of the 
physical environment. Ministerio de Obras Públicas y Transporte, Madrid, Spain [in Spanish].

Morell, J. and S. Barber. 1983. Chufa y horchata: Physical, chemical and nutritional characteristics. Agroquímica y Tecnología de Alimentos (CSIC), Valencia, Spain [in Spanish].

Pascual, B., J.V. Maroto, S. López-Galarza, A. San Bautista, and J. Alagarda. 2000a. Chufa (Cyperus esculentus L. var. sativus Boeck.): An unconventional crop. Studies related to applications and cultivation. Econ. Bot. 54:439-448.

Pascual, B., S. López-Galarza, J. Alagarda, A. San Bautista, and J.V. Maroto. 2000b. Selection and characterization of 'chufa' cultivars (Cyperus esculentus L. var. sativus Boeck.). Acta Hort. 523:37-44.

Pascual, B., S. López-Galarza, J. Alagarda, J.V. Maroto, S. López-Galarza, J. Alagarda, and V. Castell Zeising. 1997. Studies in chufa crop. Generalitat Valenciana, Conselleria de Agricultura, Pesca y Alimentación, Valencia, Spain [in Spanish].

Pascual-Seva, N., B. Pascual, A. San Bautista, S. López-Galarza, and J.V. Maroto. 2009. Growth and nutrient absorption in chufa (Cyperus esculentus L. var. sativus Boeck.) in soilless culture. J. Hort. Sci. Biotechnol. 84:393-398.

Soil Survey Staff. 2010. Keys to soil taxonomy. 11th Ed. USDA-NRCS, Washington DC.
Statistical Graphics Corporation. 2005. Statgraphics Plus for Windows 5.1. Statistical Graphics, Rockville, MD.

Umerie, S.C., E.O. Okafor, and A.S. Uka. 1997. Evaluation of the tubers and oil of Cyperus esculentus. Bioresour. Technol. 61:171173.

UPOV (International Union for the Protection of New Varieties of Plants). 2011. International convention for the protection of new varieties of plants of Dec. 2, 1961, as revised at Geneva on Nov. 10, 1972, on Oct. 23, 1978, and on 19 Mar. 1991. 12 Nov. 2012. <http//www. upov.int/upovlex/es/conventions/\%201991/ act $\% 201991$.html $>$. 